\title{
Improving the quality of literature reviews in chemistry: tools and techniques
}

Elsa Alvaro ${ }^{1}$ and David A. Zwicky, ${ }^{2, *}$

1 Northwestern University Libraries, Northwestern University, Evanston, Illinois, 60201, United States; orcid.org/0000-0001-5915-5697

2 Libraries and School of Information Studies, Purdue University, West Lafayette, Indiana, 47907, United States; orcid.org/0000-0002-2702-0840; Email: dzwicky@purdue.edu 
Appendix 1: Examples of different review types, from different chemistry and chemistry-related subject areas.

Narrative

(1) Hwang, J.; Xu, C.; Agnew, R. J.; Clifton, S.; Malone, T. R. Health Risks of Structural Firefighters from Exposure to Polycyclic Aromatic Hydrocarbons: A Systematic Review and Meta-Analysis. Int J Environ Res Public Health 2021, 18 (8), 4209. https://doi.org/10.3390/ijerph18084209.

(2) Erinc, A.; Davis, M. B.; Padmanabhan, V.; Langen, E.; Goodrich, J. M. Considering Environmental Exposures to Per- and Polyfluoroalkyl Substances (PFAS) as Risk Factors for Hypertensive Disorders of Pregnancy. Environmental Research 2021, 197, 111113. https://doi.org/10.1016/i.envres.2021.111113.

(3) Bondarenko, O. M.; Krais, A. M.; Farrera, C. Chapter 13 - Current Challenges and Coming Opportunities in Nanoparticle Risk Assessment. In Frontiers of Nanoscience; Parak, W. J., Feliu, N., Eds.; Colloids for Nanobiotechnology; Elsevier, 2020; Vol. 16, pp 353-371. https://doi.org/10.1016/B978-0-08-102828-5.00013-9.

Scoping

(4) Adetokunboh, O. O.; Mthombothi, Z. E.; Dominic, E. M.; Djomba-Njankou, S.; Pulliam, J. R. C. African Based Researchers' Output on Models for the Transmission Dynamics of Infectious Diseases and Public Health Interventions: A Scoping Review. PLOS ONE 2021, 16 (5), e0250086. https://doi.org/10.1371/journal.pone.0250086.

(5) Klokman, V. W.; Barten, D. G.; Peters, N. A. L. R.; Versteegen, M. G. J.; Wijnands, J. J. J.; van Osch, F. H. M.; Gaakeer, M. I.; Tan, E. C. T. H.; Boin, A. A Scoping Review of Internal Hospital Crises and Disasters in the Netherlands, 2000-2020. PLoS One 2021, 16 (4), e0250551. https://doi.org/10.1371/journal.pone.0250551.

(6) Arici, C.; Ronda-Pérez, E.; Tamhid, T.; Absekava, K.; Porru, S. Occupational Health and Safety of Immigrant Workers in Italy and Spain: A Scoping Review. Int J Environ Res Public Health 2019, 16 (22), 4416. https://doi.org/10.3390/ijerph16224416.

Systematic

(7) Leso, V.; Ercolano, M. L.; Cioffi, D. L.; Iavicoli, I. Occupational Chemical Exposure and Breast Cancer Risk According to Hormone Receptor Status: A Systematic Review. Cancers 2019, 11 (12), 1882. https://doi.org/10.3390/cancers11121882.

(8) Leão, R. de S.; Moraes, S. L. D. de; Gomes, J. M. de L.; Lemos, C. A. A.; Casado, B. G. da S.; Vasconcelos, B. C. do E.; Pellizzer, E. P. Influence of Addition of Zirconia on 
PMMA: A Systematic Review. Materials Science and Engineering: C 2020, 106, 110292. https://doi.org/10.1016/..msec.2019.110292.

(9) Cook, M. A.; Jagpal, P. S.; Hnin Pwint, K.; San, L. L.; Kyaw Thein, S. S.; Pyone, T.; Thit, W. M. M.; Bradberry, S. M.; Collins, S. Systematic Review of Human Poisoning and Toxic Exposures in Myanmar. International Journal of Environmental Research and Public Health 2021, 18 (7), 3576. https://doi.org/10.3390/ijerph18073576.

Meta-Analysis

(10) Fiolet, T.; Mahamat-Saleh, Y.; Frenoy, P.; Kvaskoff, M.; Romana Mancini, F. Background Exposure to Polychlorinated Biphenyls and All-Cause, Cancer-Specific, and Cardiovascular-Specific Mortality: A Systematic Review and Meta-Analysis. Environment International 2021, 154, 106663. https://doi.org/10.1016/j.envint.2021.106663.

(11) Kim, H.-J.; Hwang, H.; Hong, H.; Yim, J.-J.; Lee, J. A Systematic Review and MetaAnalysis of Regional Risk Factors for Critical Outcomes of COVID-19 during Early Phase of the Pandemic. Scientific Reports 2021, 11 (1), 9784. https://doi.org/10.1038/s41598-021-89182-8.

(12) Aramjoo, H.; Farkhondeh, T.; Aschner, M.; Naseri, K.; Mehrpour, O.; Sadighara, P.; Roshanravan, B.; Samarghandian, S. The Association between Diazinon Exposure and Dyslipidemia Occurrence: A Systematic and Meta-Analysis Study. Environ Sci Pollut Res 2021, 28 (4), 3994-4006. https://doi.org/10.1007/s11356-020-11363-1.

Critical

(13) Chernoff, N.; Hill, D. J.; Diggs, D. L.; Faison, B. D.; Francis, B. M.; Lang, J. R.; Larue, M. M.; Le, T.-T.; Loftin, K. A.; Lugo, J. N.; Schmid, J. E.; Winnik, W. M. A Critical

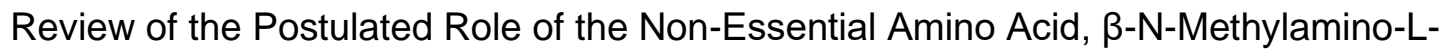
Alanine, in Neurodegenerative Disease in Humans. Journal of Toxicology and Environmental Health, Part B 2017, 20 (4), 183-229. https://doi.org/10.1080/10937404.2017.1297592.

(14) Zhong, C.; Zolfaghari, A.; Hou, D.; Goss, G. G.; Lanoil, B. D.; Gehman, J.; Tsang, D. C. W.; He, Y.; Alessi, D. S. Comparison of the Hydraulic Fracturing Water Cycle in China and North America: A Critical Review. Environ. Sci. Technol. 2021. https://doi.org/10.1021/acs.est.0c06119.

(15) Hard, G. C. Critical Review of Renal Tubule Karyomegaly in Non-Clinical Safety Evaluation Studies and Its Significance for Human Risk Assessment. Critical Reviews in Toxicology 2018, 48 (7), 575-595. https://doi.org/10.1080/10408444.2018.1503641. 
(16) Grabowski, L. E.; Goode, S. R. Review and Analysis of Safety Policies of Chemical Journals. Journal of Chemical Health and Safety 2016, 23 (3), 30-35.

https://doi.org/10.1016/i.jchas.2015.10.001. 
Appendix 2: Template for a synthesis matrix.

\begin{tabular}{|l|l|l|l|}
\hline & Source \#1 & Source \#2 & Source \#3 \\
\hline Theme \#1 & & & \\
\hline Theme \#2 & & & \\
& & & \\
\hline
\end{tabular}

